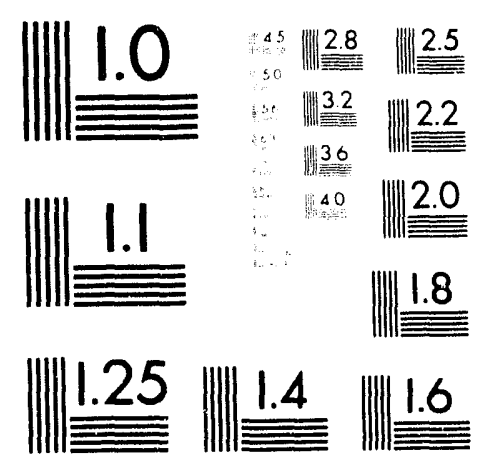



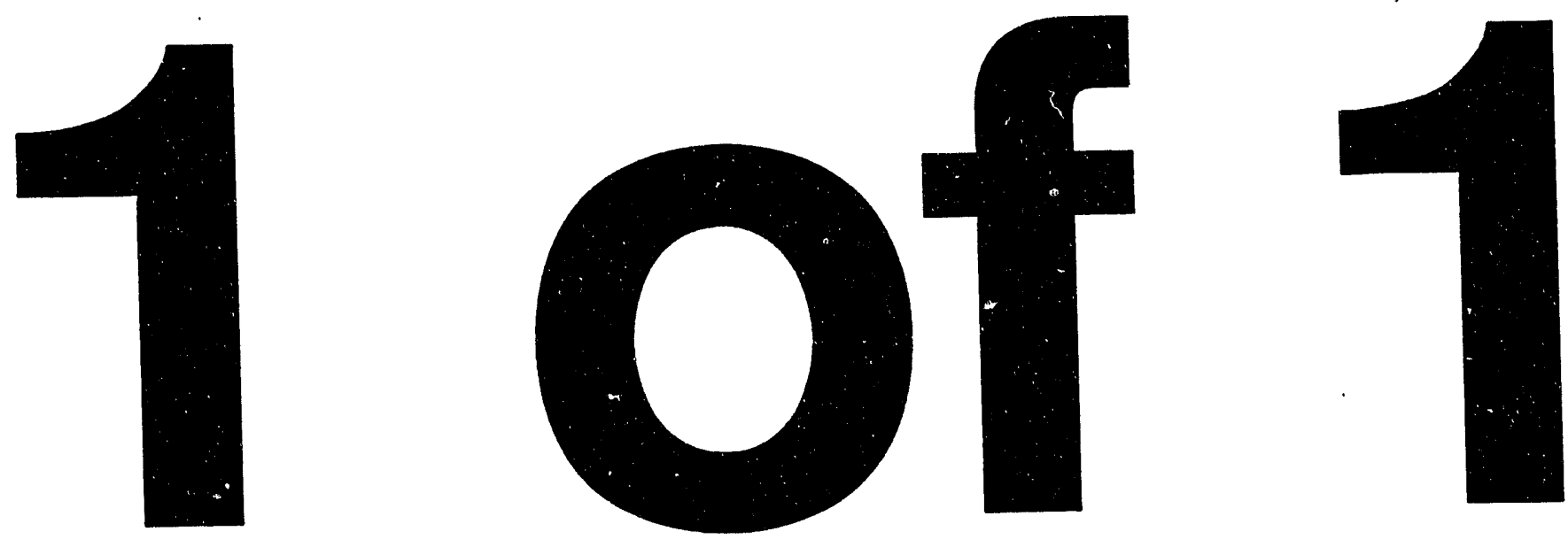
NUREG-1479

\section{Results From Two Workshops: Developing and Amending Regulations and Funding State Radiation Control Programs}

Manuscript Completed: September 1992

Date Published: September 1993

Office of State Programs

U.S. Nuclear Regulatory Commission

Washington, DC 20555
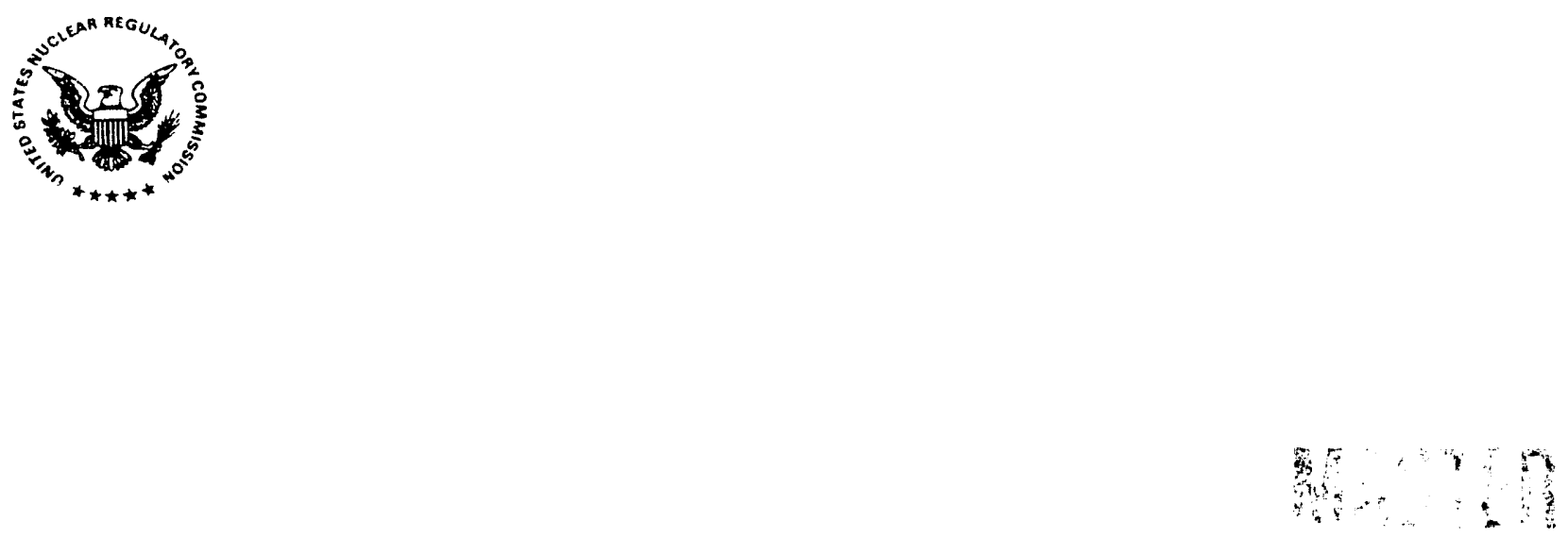
This publication was prepared by employees of the U.S. Nuclear Regulatory Commission. It expresses opinions that do not necessarily represent a staff position of the NRC; this publication has neither been approved nor disapproved. 


\begin{abstract}
The first section of this document presents the results of a technical workshop on the process of regulations development and amendment sponsored by the Nuclear Regulatory Commission (NRC). This workshop focused on methods for reducing the time it takes to promulgate regulations to help those States that are having difficulty meeting the three-year deadline for adopting new NRC regulations. Workshop participants responded to six questions. reviewed the procedures used by various States for revising snd adopting changes to their regulations, and reviewed the time-flow charts used by various States. This workshop was designed to provide guidance to States that are promulgating and revising regulations.
\end{abstract}

ABSTRACT

The second section of this document summarizes the proceedings of a technical workshop, also sponsored by the NRC. on funding radiation control programs that emphasized fee schedules and effective strategies for the 1990s. This workshop focused on determining the true costs of running a program, on setting realistic fees for the various categories of licenses, and on the most efficient methods for sending invoices, recording receipts. depositing money received, and issuing licenses. Workshop participants responded to seven questions: reviewed the methods various States use to determine true costs; reviewed the procedure that the various States use to produce invoices and licenses: reviewed the procedures that the States are required to abide by when they reccive moncy; and reviewed the method used by the NRC 10 determine the cost of its various programs. 


\section{ACKNOWLEDGMENTS}

Dr. Gerald Parker, moderator of the workshops, prepared the manuscript for this report with assistance from staff members of the Office of State Programs.

The contents of Section 1 of this report are the product of a workshop of 30 States and Federal representatives, most of whom have regulatory responsibilities for radiation safety. In addition, representatives of the NRC met with representatives of the National Association of Attorneys General (NAAG), the National Governors' Association (NGA), and the National Conference of State Legislatures (NCSL), both before the workshop and after the workshop.

\section{Representatives from the States}

Rita Aldrich, NY

Virgil Autry, SC

Edgar Bailey, CA

Harold Borchert, NE

Matthew Dunn, IL*

Donald Flater, IA

Jerry Goad. CO*

Robert Hallisey, MA

Thomas Hill, GA

Wayne Kerr, IL

Jill Lipoti, NJ
Ruth McBurney, TX

Michael Mobley. TN

Charles Pierson, $\mathrm{AZ}^{*}$

Robert Quiilin, CO

Terry Strong, WA

Diane Teft, NH

John Volpe, KY

Kirk Whatley, AL

Gerald Parker, MA

Greta Dicus. AR

Eddie Fuente, MS

Representatives from the NRC, EPA, FDA,

the Conference of Radiation Control

Program Directors, NAAG, NGA, and NCSL

*Assistant Attorneys General

The contents of Section 2 of this report are the product of a workshop of 28 State and Federal representatives.

State

\begin{tabular}{l}
\multicolumn{1}{c}{ State } \\
\hline Edgar Lailey, CA \\
Hall Bohlinger, LA \\
Harold Borchert, NE \\
William Floyd, NM \\
Terry Fra, WA \\
Eddie Fue.nte, MS \\
Aubrey Godwin, AZ \\
Robert Hallisey, MA \\
Thomas Hill, GA \\
Bruce Hokel, IA \\
Jill Lipoti, NJ \\
Daniel Nash, FL \\
Dennis O'Dowd, NH \\
Ray Paris, OR \\
Shelly Robinson, RI \\
Mary Helen Short, TN \\
Jared Thompson, AR \\
Tim Walker, OH
\end{tabular}

Carlton Kammerer, NRC

William Lahs, NRC

Cardelia Maupin, NRC

Vandy Miller, NRC

Sheldon Schwartz, NRC

Charles Froom, FDA

Floyd Galpin, EPA

Stephanie Highley, CRCPD

Eric Nelson, NAAG

Laura Armstrong, NGA

Janet Trettner, NCSL

Without the participation of the State and Federal representatives, the Conference of Radiation Control Program Directors, the National Governors' Association, the National Association of Attorneys General, and the National Conference of State Legislatures, these workshops would not have been possible.

\author{
Carlton Kammerer, OSP \\ Vandy Miller, OSP \\ Sheldon Schwartz, OSP \\ Richard Blanton, OSP \\ Jesse Funches, OC \\ James Holloway, OC \\ Glenda Jackson, OC \\ Charles Emigh, EDO \\ William Upshaw, OIP \\ Gerald Parker, OSP
}




\section{CONTENTS}

Page

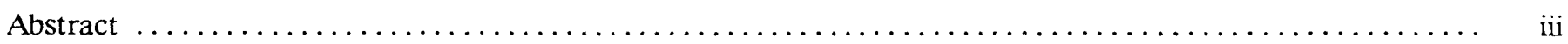

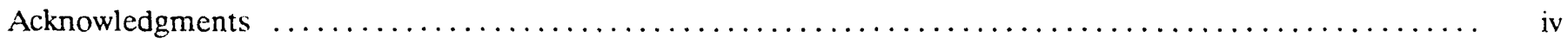

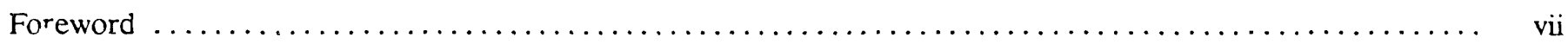

1 Workshop on the Process of Developing and Amending Regulations $\ldots \ldots \ldots \ldots \ldots$

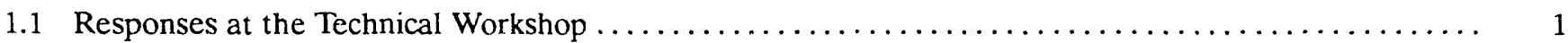

1.1.1 What are your State's political and fiscal obstacles or other limitations in adopting regulations which have been designated as matters of compatibility within the three-year time period established by NRC?

1.1.2 What are the advantages and disadvantages of coordinating Federal and State rulemaking on major issues? ii

1.1.3 Are there things the Nuclear Regulatory Commission, other Federal agencies, or the Conference of Radiation Control Program Directors can do to assist in the rulemaking

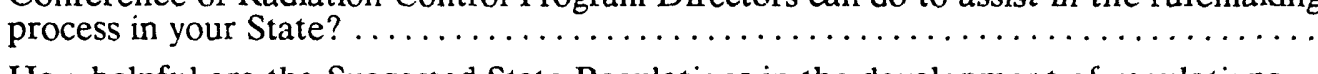

1.1.4 How helpful are the Suggested State Regulations in the development of regulations

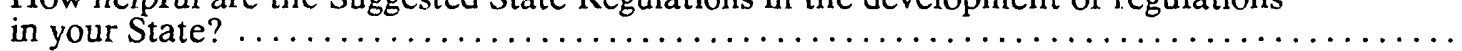

1.1.5 Are there any changes you would suggest in improving the SSR system? $\ldots \ldots \ldots \ldots$

1.1.6 Are there categories of regulations which can be adopted by reference? ............. 3

1.2 State Procedures for Revising and Adopting Changes to Regulations $\ldots \ldots \ldots \ldots$

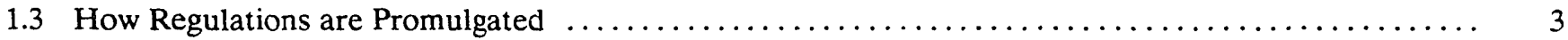

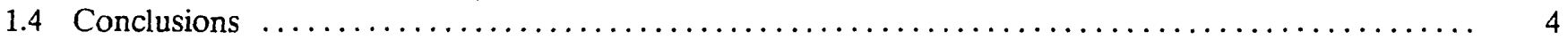

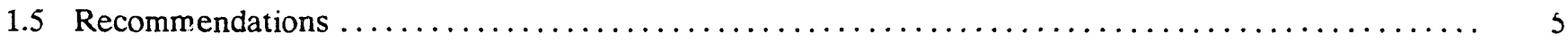

2 Workshop on Funding Radiation Control Programs with an Emphasis on Fee Schedules-Effective

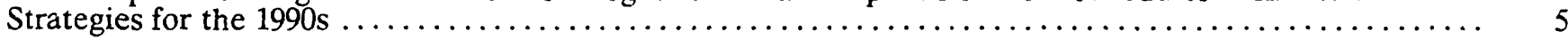

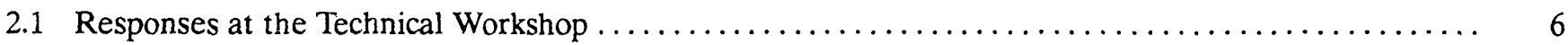

2.1.1 How does your State calculate program costs for budgeting? How are fees (if any) determined?

2.1.2 If your State charges fees, what is the system for-

- generating invoices

- receiving and recording receipts

- follow up invoices

- $\quad$ issuance of the license after fees are paid?

2.1.3 Is the Radiation Control Program responsible for the tasks in the question in Section 2.1.2? If the answer is no, what organization is responsible?

2.1.4 If your State charges fees, what problems have occurred in the process of collecting them? ....

2.1.5 Should the States develop standard fees? .............................

2.1.6 If your State has a dedicated fund, what were the strategies used to convince the legislature to authorize it? If your State considered but did not adopt a dedicated fund, what were the arguments against it?

2.1.7 If your State has considered but not adopted fees (or considered, but not passed legislation allowing fees, ) what were the arguments against them?

2.2 Conclusions

2.3 Recommendations . 


\section{APPENDICES}

A April 11, 1991, Memorandum from Samuel J. Chilk to James M. Taylor and Harold R. Denton .................................................... 11

B June 25, 1991, Memorandum from Samuel J. Chilk to James M. Taylor and

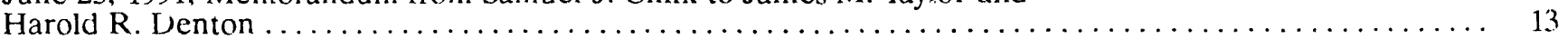

C Comments on the Suggested State Regulations for Control of Radiation; Talk Given by

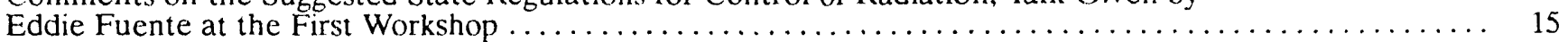

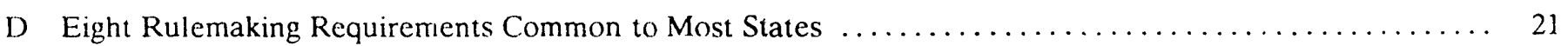

E NRC Fees for Fiscal Year 1992 and Proposed Fees for Fiscal Year $1993 \ldots \ldots \ldots \ldots \ldots \ldots \ldots \ldots \ldots \ldots .23$ 


\section{FOREWORD}

This document summarizes information from the proceedings of two workshops on subjects selected for their timely irnportance to both the Agreement States and to the NRC. The first workshop was held in the fall of 1991 on the process of adopting regulations, and the second workshop in the spring of 1992 on licensing fees and State program funding. I believe that this information will be useful to the Radiation Control Program Directors of current Agreement States, as well as to those Non-Agreement States contemplating an agreement with the NRC.

From our reviews of Agreement State Programs we have noted two areas that need focus. The first is the States' ability to provide continuing financial support for their programs, and the second is the States' ability to adopt those new NRC regulations considered matters of compatibility within three years. The sharing of experiences and information about what works and why during these workshops provided some ideas on how to meet these challenges. Particularly noteworthy were several unique suggestions on rule-adoption strategy and fee-schedule design.

We appreciate the participation of those Agreement States that sent their representatives to participate in the workshops. In a wider sense, all of the Agreement States contributed by submitting information that the workshop participants used.

The participation of a number of members of the following organizations is also recognized and appreciated: the National Governors Association, the National Conference of State Legislators, the National Association of Attorneys General, the Organization of Agreement States, and the Conference of Radiation Control Program Directors. The combined effort of many individuals and organizations was required to hold the workshops and to assemble the information for this report.

Special thanks must go to Dr. Gerald Parker, who moderated the workshops and prepared the manuscript. Thanks also to the NRC staff members, both from the Office of State Programs and from such other NRC Offices as Nuclear Materials Safety and Safeguards, the General Counsel, and the Controller who contributed to the success of these workshops.

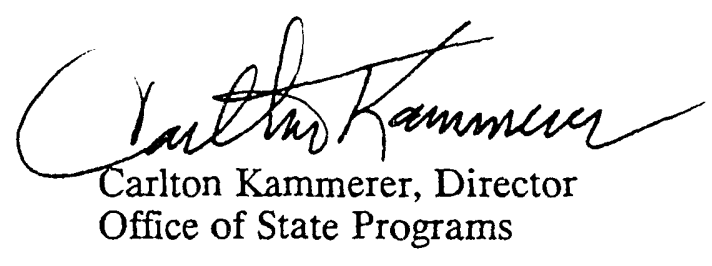




\section{WORKSHOP ON THE PROCESS OF DEVELOPING AND AMEND- ING REGULATIONS}

Congress enacted section 274 in an amendment to the Atomic Energy Act in 1959. This amendment authorized State governments a role in regulating nuclear matters. Although the Constitution delegated the protection of public health and safety to the States, the States were not authorized a role in byproduct materials regulation until the passage of the 1959 amendment. The amendment provided a statutory basis for the Federal government to relinquish its authority to the States. The States, however, are required to adopt regulations that are compatible with Federal regulations. NRC's policy statement requires that:

"The State must have regulations essentially identical to 10 CFR Part 19, Part 20 (radiation dose standards, effluent limits, waste manifest rule and certain other parts), Part 61 (technical definitions and requirements, performance objectives, financial assurances) and those required by UMTRCA, as implemented by Part 40.

"The State should adopt other regulations to maintain a high degree of uniformity with NRC regulations.

"For those regulations deemed a matter of compatibility by NRC, State regulations should be amended as soon as practicable but no later than 3 years."

Furthermore, before an agreement between the Commission and States can be finalized, the Commission must find:

"Whereas, the State and the Commission recognize the desirability and importance of cooperation between the Commission and the State in the formulation of standards for protection against hazards of radiation and in assuring that State and Commission programs for protection against hazards of radiation will be coordinated and compatible." (Page 1, paragraph 4 of an Agreement between NRC and a State)

Finally, each signed agreement states (in Article VI):

"The Commission will use its best efforts to cooperate with the State and other Agreement States in the formulation of standards and regulatory programs of the State and the Commission for protection against hazards of radiation and to assure that State and Commission programs for protection against hazards of radiation will be coordinated and compatible. The State will use its best efforts to cooperate with the Commission and other Agreement States in the formulation of standards and regulatory programs of the State and the Commission for protection against hazards of radiation and to assure that the State's program will continue to be compatible with the prosram of the Commission for the regulation of like materials. The State and the Commission will use their best efforts to keep each other informed of proposed changes in their respective rules and regulations and licensing, inspection and enforcement policies and criteria, and to obtain the comments and assistance of the other party thereon."

This technical workshop met on September 18 and 19 , 1991, to determine possibilities for making it easier for States to adopt NRC regulations. Participants addressed how a regulation is developed and the time required to adopt it. To prepare for the workshop, participants were (1) given a list of six questions that they were to answer and (2) given a compilation of the Agreement States' responses to the request to "describe your State's procedure for revising and adopting changes to regulations." Participants were requested to prepare a time-flow c':art indicating how long it takes to adopt as a final State regulation an NRC regulation that is a matter of compatibility.

\subsection{Responses at the Technical Workshop}

1.1.1 What are your State's political and fiscal obstacles or other limitations in adopting regulations which have been designated as matters of compatibility within the three-year time period established by NRC?

Although participants did not believe that they encountered significant political problems within their respective agencies, they did encounter delays when the regulations were sent to other governmental bodies such as legislative committees, the secretariats, the governor's office, the secretary of State or advisory committees, and the regulated community or advocacy groups. Too often the regulations disappeared into one of these offices and did not reappear for months.

A simple solution would be for a sentence to be included in the transmittal letter stating that failure to receive a 
response within 3 months would indicate that a particular cntity had no objection to the regulation. However, if approval is required by an Administrative Procedures Act (APA) or by statute or regulation, the Commissioner or Director to whom the Director of Radiation Control Program (RCP) reports should write a letter to the office promulgating the statute or regulation asking for an immediate reply.

The participants expected that significant fiscal problems would have to be addressed during periods of fiscal restraint. Addressing these problems is particularly important for small RCPs because, as they transfer people into rulemaking, they are reducing the staff available to do regulatory work. For all RCPs, financial resources will be needed to cover the costs of conducting hearings, printing the regulations, and postage. The fee structure should include the resources needed for these costs.

Additional problems that were mentioned during the discussion of the first question are as follows:

\subsubsection{Process}

The process itself is time consuming and costly because the person-hours that have to be devoted to writing regulations could be better spent on regulatory matters. The language that is used in NRC regulations is sometimes not compatible with State requirements. Seeking information from the States early in NRC's regulation development process would help to alleviate this problem. In addition, some States have a style manual that facilitates promulgating regulations by indicating what is required either by the APA or by another statute.

\subsubsection{Time Constraints}

Some States have to complete writing a regulation within a certain period, or they have to begin the process as outlined in the APA all over again. Other States have Sunset laws that require them to renew their regulations every few years. Thus, some States are renewing their existing regulations at the same time they are trying to adopt new regulations.

\subsubsection{Legislation and Regulations}

Non-Agreement States that wish to enter into an agreement with the NRC need time to have the enabling legislation passed. Agreement States also need time to obtain the authority to regulate new areas. All states would benefit from receiving the Suggested State Regulations (SSRs) in a more timely fashion. (The SSRs will be discussed in greater detail in Section 1.1.5.)

\subsubsection{Education}

The public, the regulated community, and the political establishment must be cducated about the necessity for developing these regulations. The educational process should emphasize the health and safety reasons for developing the regulations and the benefits of having the State rather than a Federal agency regulate the programs.

\subsubsection{The Regulated Communities}

The regulated communities need to be more involved in developing regulations. A broad-based advisory committee should include representatives from the utilities, academia, and producers of nuclear materials. This committee could be helpful in resolving controversial regulatory language to fit local conditions and in facilitating the formal promulgation process.

\subsubsection{The Public}

Since the public is somewhat suspicious of both regulatory agencies and the regulated communities, the public at large should be amply represented on advisory committees. The people chosen should be representative of all points of view on the radiation questions, which may prevent allegations that the committee is partial towards one side or another.

\subsubsection{What are the advantages and disadvantages of co- ordinating Federal and State rulemaking on major issues?}

Involving the States in NRC rulemaking makes sense because two-thirds of the materials licensees are regulated by the States. The States are required by their agreement to coordinate rulemaking with the NRC. The signed agreement also requires the NRC to coordinate its rulemaking with the States. Both the States and the NRC should clearly understand that developing a regulation is a distinct process from implementing a regulation. The States have requested that they become involved with the NRC rulemaking process at the earliest possible moment, and the NRC staff has been directed to comply with this request (Appendices $A$ and $B$ ). However, the States believe that they should participate in the discussion about whether a regulation is necessary and whether the States' regulations have to be compatible with any new NRC regulation. If the States are involved from the beginning in discussions about new regulations, the language and the rationale for these regulations will be developed in a form that will reduce the time it takes for State regulations to be promulgated. The States will also better understand why these regulations are necessary.

The biggest problem that the States face is the impossible task of developing and promulgating regulations 
simultaneously with the NRC. However, if the process outlined in the previous paragraph were followed, this problem would be reduced

\subsubsection{Are there things the Nuclear Regulatory Commis- sion, other Federal agencies, or the Conference of Radiation Control Program Directors can do to as- sist in the rulemaking process in your State?}

The NRC can play a significant role in getting State regulations promulgated by appearing at public hearings and supporting the States' efforts to protect the public health and safety. However, the NRC should only appear at hearings if $i t$ is invited as there are several States in which an NRC presence may cause problems. The participants indicated that the $\mathrm{NRC}$ is very responsive to requests to attend meetings.

Participants stated that States do not have the resources to corrduct research, therefore, the NRC is encouraged to supply the States with the background material on the scientific reasons for developing the regulations.

The participants thought that the NRC and the Conference of Radiation Control Program Directors (CRCPD) should review proposed regulations and return the comments in a more timely fashion. They also felt the CRCPD should supply the SSRs in a more timely fashion. If the CRCPD and the NRC are able to reduce the time it takes to review and return States' material to them, this reduction would in turn reduce the pressure on the States and make meeting the 3-year timetable easier.

1.1.4 How helpful are the Suggested State Regulations in the development of regulations in your State?

The summary of responses for Section 1.1.5 includes the responses for this question.

\subsubsection{Are there any changes you would suggest in im-} proving the SSR system?

Before this topic was discussed, Eddie Fuente from Mississippi provided background information on the SSRs (Appendix C).

Apparuntly the SSRs have greatly assisted the States with their regulatory process. In addition to the comment made previously about the timeliness of the production of the SSRs, the participants wanted to expand the rationale statements for their regulations. The NRC, as indicated in Section 1.1.3, could help the States in this area. The SSRs should always include the date that a section was adopted so that the States will know who worked on that section and can determine what the rationale was for adopting that scction.

\subsubsection{Are there categories of regulations which can be adopted by reference?}

Some States do adopt certain categories of regulations by reference. However, most participants believed that the language in the regulations had to be changed to meet State requirements. Furthermore, the time it takes to develop a regulation could be shortened if regulations were developed by the CRCPD and the NRC with appropriate language and rationale statements. This would require that the CRCPD and the NRC closely cooperate with the States in the rulemaking process.

\subsection{State Procedures for Revising and Adopting Changes to Regulations}

Appendix D is a summary of the information from 24 States. Note that only about three-fourths of the report ing States must hold public hearings. The public interest can only be protected if a public hearing is held. Ali States should be encouraged to conduct public hearings to receive comments from the public and the regulated community.

Clearly, regulations may be delayed as they go through legal review or when they are submitted to another office within the government. Everything possible must be done to eliminate the bottlenecks that prevent some States from getting their regulations promulgated within 3 years. As suggested previously, deadlines should be placed on the government body to which the regulations are transmitted.

\subsection{How Regulations are Promulgated}

Each State has to follow its own APA. The staff working on the regulations must be thoroughly familiar with the APA. Because the style and language of a regulation are prescribed by a State, each State needs to develop a style manual consistent with the requirements of all organizations involved so that regulations will not be rejected by another governmental body because the style is incorrect.

To reduce the time that it takes for governmental bodies to officially review a regulation, these bodies should be involved in either drafting the regulation or reviewing it before it officially reaches their respective offices.

Some States take as little as 6 months to promulgate a regulation, while other States take as long as 3 years. An example of a 6-month time line is as follows: 


\begin{tabular}{|c|c|}
\hline Day & Action \\
\hline 1 & Receives NRC regulation \\
\hline $2-7$ & Assigns staff to prepare State regulation \\
\hline $8-37$ & $\begin{array}{l}\text { Determines where it belongs in state regula- } \\
\text { tions; regulation developed from SSRs or } \\
\text { from NRC regulations with proper State } \\
\text { words and format }\end{array}$ \\
\hline 38 & $\begin{array}{l}\text { Distributes proposed regulation to- } \\
\text { - Board of Health (approving authority) } \\
\text { - Advisory community (includes regulated } \\
\text { community) }{ }^{1} \\
\text { - Other State decision makers }{ }^{1}\end{array}$ \\
\hline
\end{tabular}

64 Board of Health meets and authorizes proceeding; if not, resolves objections and starts over

66 Files notice of intended action

68 Receives comments from NRC, advisory committee, and other State agencies

68-82 Changes regulation as the result of comments received

83 Publishes regulation as notice of intended action

104 Holds public hearing to receive comments from the general public

105-126 Changes regulation as the result of comments at public hearing

127 Returns regulation to Board of Health for approval of adoption notice; if not approved, resolves objections and starts over

129 Files regulation as adopted

143 Publishes notice of adoption

178 Regulation becomes effective

When other governmental agencies, concerned citizens, the regulated community, and an advisory committee are involved from the time the RCP initiates the drafting

'These groups have 30 days to submit comments. process. a State may take only 6 months 10 implement a regulation.

Advisory committecs should be given a limited time to review the proposed regulation before it is published. By the time the regulation is published, it should have been reviewed by interested parties, and the staff should have had an opportunity to consider their comments.

The advantage of this process is that other governmental bodies and the regulated community as well as the concerned community will have already reviewed the regulation before the public hearing. Consequently, most concerns will have been addressed before the regulations are discussed at a public hearing.

The RCPs should not attempt to repromulgate their existing regulations while attempting to adopt new NRC regulations. The process becomes very complicated when two different sets of regulations are being worked on simultaneously. The individual States should work with the NRC to determine when new regulations required by the NRC can best be adopted while sunset law requirements are being met.

When a change in a State statute is required for the State to promulgate a regulation compatible with a new NRC regulation, States with legislatures that meet only once every 2 years will find it almost impossible to meet the 3 -year deadline. Therefore, the NRC should work closely with the States so that new NRC regulations will not require changes in State statutes or, if a State statute must be changed, the NRC should attempt to ensure that the State will have adequate time to obtain legislative approval.

\subsection{Conclusions}

(1) The SSRs have proven to be very useful. States have and should continue to take advantage of this resource.

(2) Some States have no problem in meeting the 3-year deadline by working closely with other State agencies, the regulated community, advisory committees, and the NRC while the regulation is being drafted. By doing this, all of the groups enumerated have had their conc'sms aired and hopefully addressed before the regulation is officially advertised.

(3) States historically have not been involved early in NRC's rulemaking process or compatibility determinations. The Commission has attempted to address this problem in the April 11 and June 25, 1991, memoranda. 
(4) The costs of the rulemaking process isually have not been inciuded in fees. The fees should be changed to include the rulemaking process costs, which have continued to rise. The NRC. using information from the States, should determine these rulemaking costs and include them in the fees is a separate item.

(5) Some States whose legislatures meet every 2 years have had nroblems meeting the 3-year deadline if the reguidion change recuired a change in State law or other legislative approval.

\subsection{Recomrnendations}

(1) The States and the NRC should become true paitners. The NRC should invite State representatives to be present when the decision-making process about new regulations is initiated. Subsequently, State representatives should be consulted when the compatibility determinations are being considered.

(2) The States should be involved in the development of NRC regulations to ensure that the language of the regulations is compatible with State requirements. The NRC should develop the underlying rationale for each regulation so that this rationale can be presented during NRC and State public hearings.

(3) The States, through the CRCPD, should develop the SSRs in a more timely fashion as delays have occurred when the SSRs were not available. Additonal resources may be required to accomplish this.

(4) The NRC should review proposed regulations from the States in a more timely fashion.

(5) When requested, the NRC should continue to testify at State public hearings.

(6) The States must include the expenses of rulemaking as part of their fee structure.

(7) NRC specialists should be present at State workshops when their specific area of expertise is associated with the topic being discussed.

\section{WORKSHOP ON FUNDING RA- DIATION CONTROL PRO- GRAMS WITH AN EMPHASIS ON FEE SCHEDULES - EFFEC- TIVE STRATEGIES FOR THE $1990 \mathrm{~S}$}

The Federal Omnibus Budget Reconciliation Act of 1990 (OBRA-90) requires that the NRC recover approximately 100 percent of its budget through fees for Fiscal Years 1991 through 1995.2 This requirement means that the NRC has to collect fees to fully cover the costs of conducting its programs, including the collection of fees from State and local governments, which had previously been exempted from paying fees. As a result of the regulations promulgated to comply with OBRA-90, only nonprofit educational institutions are exempted from annual fees in P; $\mathrm{rt} 171$ of Title 10 of the Code of Federal Regulations (10 2FR Part 171). Both nonprofit educational institutions and Federal agencies are exempt from licensing and inspection fees (10 CFR Part 170).

The NRC had to examine its budgeted costs and allocate these costs to major classes of licensees in order to establish the fees that would generate sufficient revenue to cover the budgeted costs. The NRC is required to charge a fee for any services provided, such as reviewing an application or an amendment, or developing regulations; and for overhead, including the cost of running the Office of State Programs.

The present economic environment is forcing nearly all government agencies to carefully review the need for each of their programs and their related funding. State RCPs have not been excluded from this review process. Some RCPs already recove. full program costs through fees. The NRC expects that in the near future, most if not all State RCPs will be required to generate sufficient revenue to recover approximately 100 percent of their budget from fees just as the NRC is now required to do.

The technical workshop that took place on April 28 and 29, 1992, systematically explored the budgetary pressures RCPs are facing and reviewed funding alternatives to identify effective strategies for funding these RCPs in the future. The determination of real costs was addressed.

Before the workshop, participants were given a list of seven questions for which they were requested to prepare answers that would be presented at the workshop.

2For an example of the NRC fee structure, see Appendix E 


\subsection{Responses at the Technical Workshop}

2.1.1 How does your State calculate program costs for budgeting? How are fees (if any) determined?

Some of the RCP participants described novel methods for determining and then assessing their fees. These ranged from fees based on the quantity of radioactive material licensed to fees as a percentage of NRC fees. However, most sought to correlate the fees with their program cost. Methods used to determine costs included time studies, activity reports, estimates of the number of full-time equivalent staff positions needed to conduct programs, utilizing data collected by nearby States, and adding a percentage for indirect costs and fringe benefits, where appropriate.

Clearly, many State RCPs did not know what their true costs were because other governmental programs within their agency or State were paying for the costs of telephone service, energy, rent, maintenance, and calibration of instruments, legal support, transportation, administrative support, hearings, publishing and disseminating regulations, and emergency response costs.

To help prepare for the day when all States will be required to generate revenues to recover the true costs of their programs, the RCPs should begin to gather data on the following costs that were identified from presentations at the workshop:

(1) Time for licensing and registration activities:

- Application review

- Issuing of licenses and registrations

- Issuing of amendments

(2) Time to prepare for inspections and investigations

(3) Inspection and investigation time

(4) Report writing and compliance correspondence time

(5) Travel time

(6) Training time

(7) General office time

(8) Supervisor's time

(9) Secretarial time
(10) Costs of instruments, including purchases, maintenance, calibration, repair, shipping, and replacement

(11) Building costs, including rent, energy, and telephone and water service and their maintenance

(12) Travel costs, including automobiles, gas, maintenance, and replacement

(13) Fiscal, administrative, postage, copier, and computing costs, and costs for supplies, new equipment, and word processing

(14) Costs of regulations, including meetings of advisory committees, preparation of regulations, printing and distribution of regulations, advertising the hearin $\tilde{\varepsilon}$ s on the regulations, and legal services

(15) Emergency response costs

Only when nianagers of the RCPs are able to determine their real costs will setting fees that will pay for their programs be possible. The participants believed that from a programmatic point of view, setting fees and adjusting them within a short time because they were set incorrectly would be inappropriate. The anticipated effect of inflation during the period for which the fees are being established must be factored into the fee determination. Adjusting fees frequently can cause serious political probler.is both with governors' offices and with State legislatures as well as with the regulated community and the public. The setting of fees must be undertaken with the utmost care and must be done only after carefully gathering data on the costs of each of the items previously listed. In addition, States should consider the effect that raising the fees will have on local inflation.

\subsubsection{If your State charges fees, what is the system for-}

- generating invoices

- receiving and recording receipts

- followup invoices

- issuance of the license after fees are paid?

The summary of responses for Section 2.1.4 includes the respenses for this question.

2.1.3 Is the Radiation Control Program responsible for the tasks in the question in Section 2.1.2? If the answer is no, what organization is responsible?

The summary of responses for Section 2.1.4 includes the responses for this question.

2.1.4 If your State charges fees, what problems have occurred in the process of collecting them?

Overall, States that utilize computers (1) to send out invoices, (2) to generate licenses after fees have been 
received, and (3) to track exch licensee appear to most efficiently carry out these functions. These States use a data system that has allowed them to reduce the staff required to complete these functions.

For example, a State that generates invoices and receipts by hand needs a full-time clerk for every 400 licensees in a Radioactive Materiai Program, while on the other hand, a State that utilizes the most up-to-date equipment and sof tware is able to oversee approximately 4000 registrants in an X-ray Registration Program with one clerk. Although administering a Radioactive Material Licensing Program is more difficult because of the complexity of the program (which includes application review, amendments to the license. frequent inspections, and a higher level of risk). the participants concluded that a difference of a factor of 10 in productivity between these programs is ton great a difference.

Tr. cem the NRC uses is an example of another option ava.sable. While many States send their own invoices, the NRC has a contract with a mailing service to send its invoices. The contractor is responsible for assembling and folding up to five pages of material to be mailed, inserting the documents into a window envelope with the address showing. sealing the envelopes, stamping the envelope with the return address, and delivering the envelopes to a specified L'S. post office. The cost of this service is approximately 20 cents an envelope for approximately 10,000 annual fee invoices.

The great majority of State: hat receive money are required to deposit it every day. However, some States can take from a week to a month to deposit money. In the case of the NRC, money is not received by the agency but is ent directly to a "Lock Box" bank at no cost to the NRC vecause the bank receives payment from a treasury contract through a "compensating balance" arrangement. This bank is responsible for receipt and deposit of billed fees. Payment data is downloaded from the "Lock Box" bank to the NRC's accounts receivable system on a daily basis

The States may wish to contact their local banks to determine whether such banking arrangements are possible and also to check with other State agencies, such as the tax office, to see if such a contract already exists between the State government and a bank that the RCP could utilize.

Tre NRC and some States generally issue followup invoices after 30 days. If licensees fail to pay, some States and the NRC issue orders suspending or terminating the license while other States refer the matter to either their State agency's legal department or to the Office of the State Attorney General. However, most legal depart- ments are not interested in filing a claim or prosecuting a company for the small amount of money that is typically involved. One State reported that its legal department was unwilling to take action against the offenders. Another State reported that it was considering taking these offenders to small claims court to collect fees.

Most States reported they did not have any problems collecting fees from the radioactive materials users. Problems occasionally arise when money is received by NonRadiation Control Program staff who are unable to respond to questions from the licensees or when the RCP staff request additional information from the Non-Radiation Control Program staff. With the exception of the participants from one State where problems occurred some years ago, the participants believe that having the RCP involved with the whole process of collecting the fees and generating the licenses is most efficient. In this way, the RCP staff are more easily able to respond to any problems that may arise. When the RCP staff indirectly receives notification that the fees have been received, the information may be mislaid and the license may not be generated. A real problem occurs when the RCP is required to send all of the invoices simultaneously, and temporary employees have to be recruited to do this work. Those RCPs that spread the workload out over a year find it much easier to keep track of all the invoices, licenses, and recripis. The participants concluded that every attempt should be made to have this part of the program operate continuously through the year.

In many States, the technical review of a new license cannot begin until the application fee has been paid. Once paid, issuance of the license can then proceed without further concern about the fees. License renewals and amendments may also proceed freely where separate fees for these actions are not charged. However, when renewal and amendment fees are charged, the State should consider a mechanism to prevent renewal or amendment issuance until the appropriate fee has been received. In some States, a review of the fee status is included as part of the technical review, thus providing an opportunity for the RCP to take appropriate action.

Some States have developed a pattern of hand delivering new licenses, complicated licenses, or unusual amendments to a license. This gives the RCP staff an opportunity to meet with the new licensees and to develop rapport that will make their subsequent regulatory work easier. Hand delivery also gives the RCP staff the time to explain their programs, especially the health and safety issues.

\subsubsection{Should the States develop standard fees?}

The participants believed that standard fees were unnecessary and that standard fees might cause problems in 
some States if the fees collected were greater than the standard fees. The participants did not want to see any fees mandated or become an issuc of compatibility.

However, participants were in favor of having a suggested list of minimum fees that could be used by any State that wished to use it. The participants believed that the listed minimum fees should reflect some reasonable estimate of minimum costs and may induce a State to review its fee structure if the State's fees only recover a small percentage of the RCP costs. In States in which low fees have been set by agencies other than the RCP, the RCP may use the suggested list of minimum fees to justify an increase.

Participants differed about the necessity of having standard categories. Comparing fees is very difficult when States do not use the same terms to describe the types of licenses. States are not able to compare fees charged by adjacent States when the categories are unclear.

Some participants believed a suggested standardized fee category would be helpful. Participants also felt that these standardized fee categories should not become an issue of compatibility and should not be mandated.

2.1.6 If your State has a dedicated fund, what were the strategies used to convince the legislature to authorize it? If your State considered but did not adopt a dedicated fund, what were the arguments against it?

The summary of responses for Section 2.1.7 includes the responses for this question.

\subsubsection{If your State has considered but not adopted fees (or considered, but not passed legislation allowing fe $\epsilon$; what were the arguments against them?}

In a number of States, agencies received authorization to establish dedicated funds. In most cases, the radioactive materials users were $r$. $t$ the main proponents of establishing dedicated funds but rather members of industries were-members such as the oil and chemical industry who already pay large amounts in taxes. These industries wanted their fees to be used by the people that were regulating them rather than have the fees go into a State general fund. They wanted to be sure that their fee dollars were being used on their behalf. The radioactive material users were in favor of dedicated funds and their support was also helpful. Without their support, problems may arise in obtaining dedicated funds. Generally speaking, the most vocal opponents to both fees and dedicated funds are the registrants involved with $\mathrm{x}$-rays. The RCP staffs have to better explain to registrants the advantages of having dedicated funds because the RCP will only be able to get dedicated funds when they have the support of the majority of the regulated community.

The executive branch in some States believes that all programs, including the RCP, should be self-supporting. In some States obtaining dedicated funds is very easy. In other States, dedicated funds are not popular because the administrative side of the executive branch loses some control over the expenditure of funds. Legislators in several States who want to keep a tight rein on purse strings also feel that they lose some control once a dedicated fund is established. In at least one State, the licensees and the registrants aren't even aware that the funds collected are not going into the RCP. One State reported that all of its dedicated funds were appropriated by the legislature after large surpluses accumulated in them. Several States have language in their statutes that allows them to carry over surpluses in their dedicated funds from one year to another. This concept is important because fees will change less often as the surplus is averaged over time. The surpluses from the first few years should cover the increased costs caused by inflation. However, a ceiling may be placed on the amount that can be carried over. Three examples of such language are:

"The moneys in this fund may be carried over from one fiscal year to the next provided that any unencumbered funds in excess of $\$ 100,000.00$ on September 30 of each year shall revert to the State - - - - general fund."

"All monies in the fund in excess of that amount necessary to administer such program shall remain in the fund, to be invested by the treasurer, until such time as either State or Federal funds become unavailable for these purposes. These excess funds shall be retained for the purpose of supplanting lost and reduced State environmental funding, or Federal environmental funding presently granted to the State."

"There shall be established in the Department a non-lapsing revolving fund. The fund shall contain a separate subaccount for fees imposed for each specific program."

States that are in the process of establishing dedicated funds should attempt to have sunilar language included in their statutes so they will be able to carry over funds from one year to the next. 


\subsection{Conclusions}

1. True costs of running an RCP must be determined before fees are set so that the fees will be realistic and will reflect real costs.

2. The regulated community is more responsive to an efficiently run RCP; that is, an RCP that is responsible for generating invoices, receiving and recording receipts, generating followup invoices, and issuing licenses; and an RCP that sends invoices continually throughout most of the year, if not year round.

3. The relationship between the RCP and the regulated community profits when the RCP explains an original license or a complicated amendment to the licensee. This explanation gives the RCP an opportunity to explain other aspects of its program, including fee structure.

4. Replacing hand written invoices, receipts, and licenses with computer generated materials will increase efficiency.

5. Developing suggested license categories would allow States to compare these categories among States, but not as a mandatory action or as a matter of compatibility.

6. Developing a suggested list of minimum fees for each category would also be helpful, but not as a mandatory action or as a matter of compatibility.
7. The support of the regulated community is desirable wher attempting to establish a dedicated fund.

\subsection{Recommendations}

1. The States through the CRCPD should develop a manual and software for a computer system that will allow those States which are not as yet using a modern system to do so, thereby reducing the staff needed to send invoices, collect fees, and generate licenses.

2. The CRCPD or the Organization of Agreement States should develop a list of suggested standardized categories and a list of suggested minimum fees to be used by those States wishing to do so.

3. The States should enlist the support of the regulated community to get a dedicated fund that can be used exclusively to support activities involving that regulated community.

4. The Statute establishing the dedicated fund should include language that will allow any money left at the end of the fiscal year to be carried over to the next fiscal year.

5. The States should develop the same relationship with other parts of the regulated community as they have with radioactive material users. 


\section{Appendix A}

\section{April 11, 1991, Memorandum}

from Samuel J. Chilk

to James M. Taylor and Harold R. Denton 


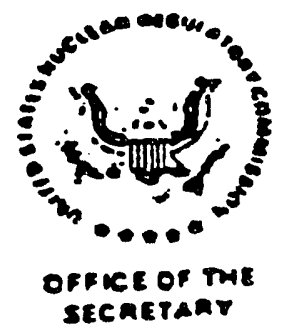

HEMORNADUS FOR:

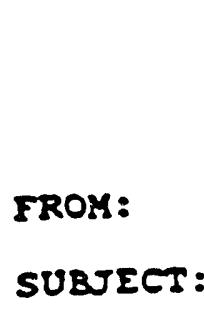

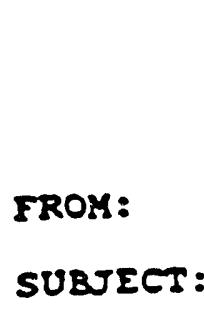

UNITEO STATES

NUCLEAR REGULATORY COMM'

WASMMETON. DE. zESA

ApI11 11. 1991

The Commission (with all commissioners agreeing) directs the staff to develop a process that will ensure early and substantial involvement of the Agreement states in rulemakings and other IIRC regulatory fforts that affect faclilties licensed under $10 \mathrm{CFR}$ $30,40,61$, and 70 or their state equivalents. In developing an $30,40,61$, and 70 or their state equivalents.
efficient process for Agreement state cooperation, ehe staff, in
consultation with the General counsel and the organizetion of Agreement states (OAS), should conslder adopting the lollowing components as a part of that process:

- Agreement seate review of WRC's regulatory agenda (NUREG-0936) to identify rulemakings of lisportance to state programs.

Provide opportunity for substantive consultation between the Agreement stetes and staff duriag the development of potential rulemakings of i=pertance to the states.

consultation on compatibility determinations that will be included in proposed rulas.

Inclusion of Agreement state vlews in a separate section of Comission papers tlat transmit proposed rules. whleb have the potentlal to affect Agreement state 11 censees.

$A$ tracking system to ensure that issues and concerns ralsed by the Agreement states are resolved in a tinely manner. 
The Commissic:. notes that GPA :roking close?y with the OAS ir. jeveloping the process should telp ensure that the process wi:have the suppest of all concested. Whlle werk moves forward ca establishing the process, tho:s=, it would te helpful to emphasize to =he OAS that the Cimmission is looking forward $t=$ further discissions with the cis at the upecing commission neeting.

$$
\text { (EDO/GPR) }
$$

\{:ECY Suspense:

$6 / 26 / 91)$

The commissior. also directs the staff to defer any further ac:ion to resolve the "Illinois 1 mili Erem issue" until the Commissis. makes a decision on SECY-91-035.

\author{
ce: Chairman carr \\ Commissicner Rogers \\ Commissicrer Curtiss \\ Commissicner Remick \\ OGC
}


Appendix B

June 25, 1991, Memorandum

from Samuel J. Chilk

to James M. Taylor and Harold R. Denton 


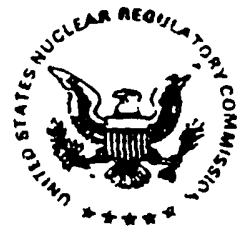

OFFICE OF THE SECRETARY

MEMORANDUY FOR:

FROM:

SUBJECT :

\author{
UNITED STATES \\ NUCLEAR REGULATORY COMMISSION \\ WASHINGTON. D.C. 20656 \\ IN RESPONSE, PLEASE \\ June 25,1991 \\ REFER TO: M910611A
}

\author{
James M. Taylor \\ Executive Director for operations \\ Harold $R$. Denton, Director
Governmental and public/preairs \\ samuel J. chilk, secrefop \\ STAFF REQUIRENENTS - BUI\$IING BY AGREE- \\ MENT STATES ON COMPATIBITTY ISSUES \\ (SECY-91-039), 10:00 A.M., TUESDAY, JUNE \\ 11. 1991, COMMISSIONERS' CONEERENCE ROOM, \\ ONE WHITE FIINT NORIH, ROCKVILTE, \\ MARYIAND (OPEN TO PUBLIC ATIENDANCE)
}

The Comission was briefed by members of the organization of Agreement states on 1ssues of compatibility in the Agreement state programs. The organization of Agreement States was represented by:

Thomas E. Hill, Chairman Organization of Agreement states

Wayne Kerr, Assistant DIrector offlce of Radiation safety Illinois Department of Nuclear safety Chairman, Agreement States Task Force on Compatibility

Greta Dicus, Director Division of Radiation control and inergency Management Arkansas Department of Health

Lavid R. Lacker, Chlef Bureau of Radiation Control Texas Department of Health

Larry Anderson, Director Bureau of Radiation Control utah Department of Health 
The commission requests that the staff seek the comments of interested parties other than the regulatory (e.g. materials users and waste generators) on the general matter of compatibility and the advantages and disadvantages of a uniform national approach to radiation safety matters. The staff should also seek comments on appropriate mechanisms to provide the states flexibility to address local needs anc conditions. The staff should provide to the Comission an analysis of the issues raised in these and the Agreement States' comments, along with recommendations on the process we should follow to develop a policy on compatibility issues. staff's recomendation should consider the joint

NRC/Agreement state task force process recomended by the organization of Agreement states as well as suggestions from other interested parties. This will serve as an added basis for Commission action on SECY-91-039.

(EDO/GPA)

(SECY Suspense: $20 / 18 / 91$ )

Cc: Chairman Carr
Commissioner Rogers
Commissioner Curtiss
Commissioner Remick
OGC
ACRS
PDR - Advance
DCS - P1-24




\author{
Appendix C \\ Comments on the \\ Suggested State Regulations \\ for Control of Radiation \\ Talk Given by Eddie Fuente \\ at the First Workshop
}




\section{SUGGESTED STATE REGULATIONS FOR CONIROL OF RADIATION}

The Atomic Energy Act of 1954, initiated itself in response 10 President Eisenhower's "Atomic Power for Peace" address to the IInited Nations Generd Assembly in December 1953, added imperus to the private development of atomic energy for peaceful purposes. The development of peaceful uses of atomic energy, under the guidance and oversight of the U.S. Atomic Energy Commission (formed in 1946, then reorganized as the United States Nuclear Regulatory Commission in 19\%15) focused public attention on many problems regarding this new industry. Along with the benefits of this technological advance came the realization that many products, such as $x$-ray machines, long in public use, created problems similar to those associated with the new atomic industry. Widespread interest in radiation protection led eventually to the enaciment of Public Law 86-373. The Atomic Energy Commission worked closely with the Council of State Governments and many state officials in developing Public Law 86-373.

Accordingly, we Council of State Govemment, the Atornic Energy Commission and the U. S. Public Health Service prepared 2 draft of proposed Suggessed State Regulations for Control of Radiation to implement state radiation control acts. They were widely distributed among public officials and private sectors for comments. The first suggested regulations were published by the Council in September 1962. These suggested regulations provided for regulation of all sources of radiacion in that they were not only designed to incorporate provisions necessary to qualify a state to assume certain of the regulatory responsibilities of the Atomic Energy Commission pursuant to Public Law 86-373, but also to provide for regulations of sources of radiaticn over which there has never been federal jurisdiction. Therefore, the suggested regulations are not only for the states which develop an overall radiation control program but also for those states which desire to regulate only those sources of 
Indiation not aubject to the NRC regulations.

Updated and revised regulations were published in 1964, 1966, 1970, 1974, 1978, and 1982. The 4th Edition (1970), dealing with radiation machines, was a revision to be consistent with the recommendations of the National Council on Radiation Protection and Mensurements (NCRP).

The Sth Edition (1974) included provisions of the electronic product ndintion anfety performance standards. It also included three new parts: Part If Radiation Safety Requirements for Analytical X-ray Equipment); Part I (Radiation Safety Requirements for Particle Accelerators) and Part J (Notices, Instructions and Reports to Workers; Inspections). Part $J$ addresses the requirements of the Occupational Safety and Health Administration of the U.S. Department of Labor by incorporating provisions from Titie 10, Code of Federal Regulations, Part 19.

The 6th Edition (1978) reflected changes in the NCRP recommendations, new amendments to the NRC regulations and amendments to the electronic product radiation safety performance standards issued by the Bureau of Radiological Health (now the National Center for Devices and Radiological Health.

The 7th Edition (1982) included the U.S. Environmental Protiction Agency Standards (Title 40 CFR), amendments to NRC and FDA regulations and a new Part $W$ addressing requirements for Wireline Services and Subsurface Tracer Studies.

Also in 1982, Volume II, Nonionizing Radiation (Lasers) was published.

An interin Edition of Volume I (lonizing Radiation) was iseued in 1984. This revision provided companion regulations consistent and in conformity with certain amendments to federal sandards. A new Part M (Licensing Requirements for Land Disposal of Radicactive Waste) wns also included.

Enough for history, let me arm lo more current events.

The CRCPD's Suggested State Regulations Working Groups, which currently total 10, consisting 
of state. local and federal government employees and in come easeconsulants develop the revisions to the regulations. For many yoars, the revised regulations were reviewed by a hard-working, dedicated group known as the Technical Review Committec. The CDRH publiched to the Eederal Register a notice of availability of the latert revisions of the SSRCR and invited interested persotis to submit cormments.

However, credit for the coordination and publication of the Surgested State Regulations goes to Charles Froom, Office of Standards and Regulations, Center for Devices and Radiological Health. Chuck Froom has been most belpful to me in the transition from the CRCPD Technical Review Committee to the Regulations Overview Committee (ROC) established by the CRCPD Executive Board in September 1988. The ROC, which I chair, and four SSRCR Working Group chaippersons with resource persons from NRC, EPA and the CDRH provide technical and clarity review of proposed and revised regulations; transmit to the Executive Director of the CRCPD revised additions and revisions of the SSRCR; and ensure the SSRCR are consistent with adopted policies and positions of the CRCPD.

In June 1989, NRC, EPA and FDA were provided the final Draft of the 8th Edition (current revision) of Volume I (lonizing Radiation) of the Suggested Sute Regulations for Control of Radiation and were requerted to approve the 8th Edition for publication.

Two of the federal agencies forwarded their concurrence letters to the CRCPD Executive Director in August and November 1989. The third federd agency requeated that come changes to cerain Parts of the Draft requlations be edopted. Upon adoption of these changes to the draft copy of Volume I of the 8th Edition, the third federl asency provided their concurrence in April 1994. At the 1990 CRCPD annual meeting, the Executive Bond of the CRCPD approved the publication of the 8th Edition of the SSRCR. New Pars T (Transportation of Radicactive Material) and U (Licensing Requirements for Source Materid Milling Facilities) were added to this Edition. 
In June 1990, the Executive Director of the CRCPD provided to an Radiation Control Program Directors the final printed copy of the 8th Edition of Volume I of the SSRCR without the new Part U. An updated draft Part $U$ was submitted to the Par $U$ Worling Group in March of this year by the NRC for their review and consideration.

As soon as the final drat of Part $U$ receives concurrence by the participating federal agencies, it will be sent to the states for inclusion in the 8th Edition of the SSRCR.

In November 1990, the CRCPD assumed the responsibility for the coordination and publication of the SSRCR. In January of this year, the CRCPD published Policies and Procedures for the Preparation and Publication of the Sugzested State Regulations for Control of Radiation which have been provided to the SSRCR working groups. The CRCPD has implemented a new system of publication. The SSRCR are now a dynamic document. Initially, a complete document will be given to all Radiation Control Program Agencies and participating federal agencies and sold through the CRCPD to other interested groups or persons and thereafter, individual pages will be furnished as revisions occur.

Current regulations being reviewed by the respective working groups:

1) NRC's Revisions to 10 CFR Parts 20 and 35

2) Part $F$ regulations addressing diagnostis $x$-ray machines and facilities.

New Pars submitted to ROC:

1) Part $X$, Therapeutic Radiation Machines

2) Part N, Natinally Occurring Radionctive Materials (NORM)

Two new Pars join Lseers in Volume $\mathbf{n}$ (Nonionizing):

1) Tanning Facilities

2) High Iotensity Discharge Lamps

In summary, I have presented some of the history in the early development of the SSRCR, 
briefly described the transition from CDRH to CRCPD for the coordination and publication of the SSRCR, and identified some current issues being addresed by the SSRCR worbing groups. 
Appendix D

Eight Rulemaking Requirements

Common to Most States

NUREG-1479 
咅
总

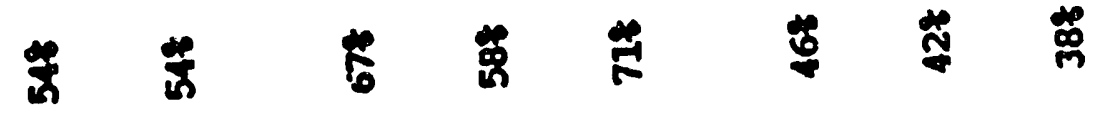
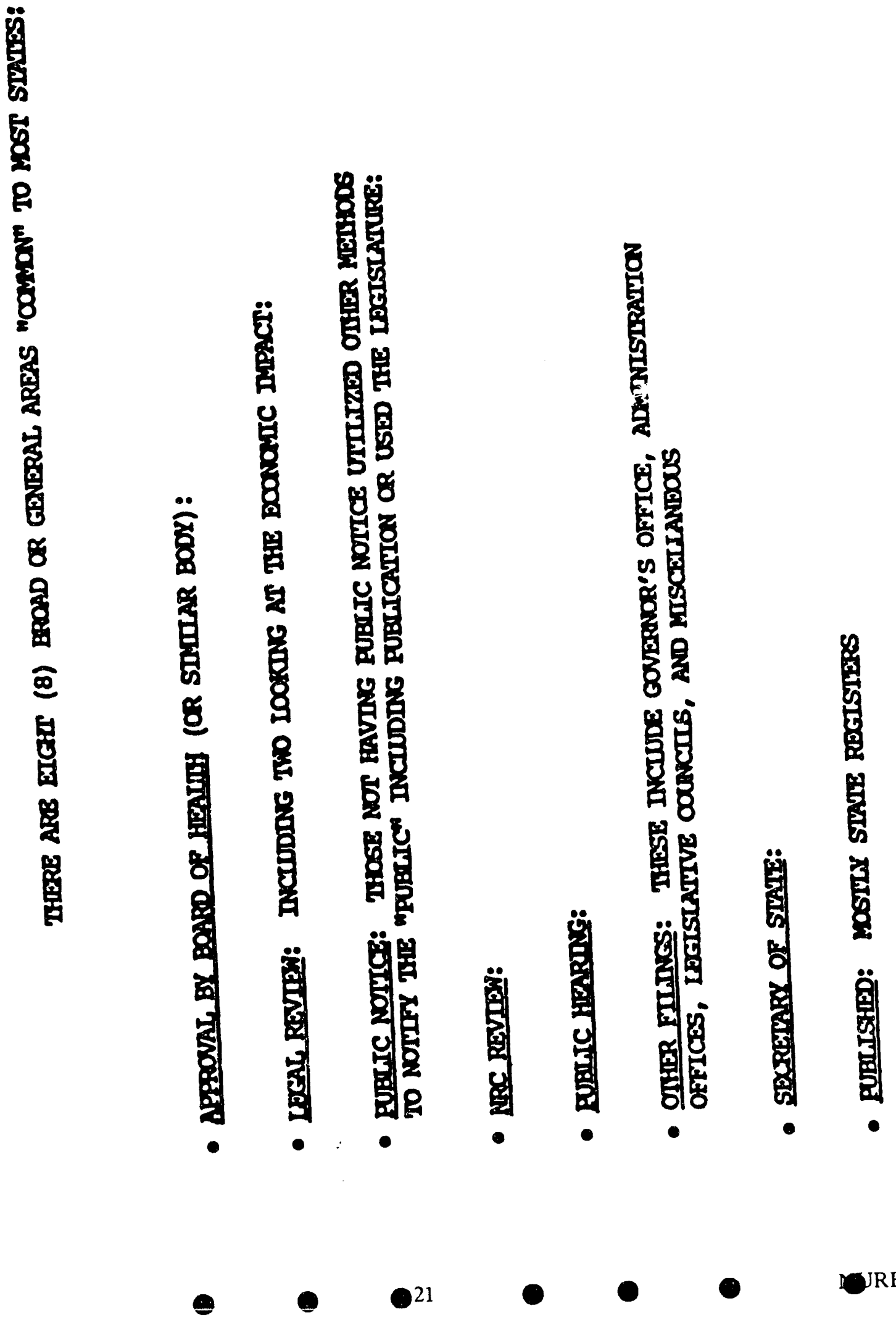
Appendix E

NRC Fees for Fiscal Year 1992

and Proposed Fees for Fiscal Year 1993 


\section{Appendix E}

\section{NRC Fees}

In general, the structure of the NRC system of fees consists of two parts, a set of fees for identifiable services (as adopted in 10 CFR Part 170) and an annual flat fee (as adopted in 10 CFR Part 171). The total fees paid by an NRC licensee in a given year will be the sum total of $t$ : $:$ annual fee plus the sum of all service fees charged for services rendered during the year.

The Part 170 (service) fees are based on the cost of staff time and the estimated staff time expended in providing specific services, such as the evaluation of an application and issuing a license or amendment, the renewal of a license, or the conducting of a license inspection. Different classes of licenses will have different costs for each service, thus different fees.
NRC is required to charge these fees under the terms of the Independent Offices Appropriation Act (31 U.S.C. 9701) and must review the estimates on which the fees are based at least every 2 years under terms of the Chief Financial Officers Act (PL 10 -576).

The Part 171 (flat) fees are based on the requirement to recover approximately 100 percent of the NRC budget, less amounts recovered by Part 170 fees or by appropriation from the Nuclear Waste Fund. These fees cover generally the Commission's overhead and the cost of activities that do not directly benefit one specific class of licensees.

The following table lists the type of fees assessed in Fiscal Year 1992 for several types of materials licenses and the fee proposed for Fiscal Year 1993. 


\section{Example of NRC fees: FY92 and Proposed FY93}

\begin{tabular}{|c|c|c|c|}
\hline License & Fee type & FY92 fee & $\begin{array}{l}\text { Proposed } \\
\text { FY93 fee }\end{array}$ \\
\hline $\begin{array}{l}\text { Medical, Broad Scope } \\
7 \text { B }\end{array}$ & $\begin{array}{l}\text { Part 170: } \\
\text { Application } \\
\text { Amendment } \\
\text { Inspection }{ }^{1} \\
\text { Part 171: } \\
\text { Fee } \\
\text { Surcharge }\end{array}$ & $\begin{array}{r}\$ 2,500 \\
390 \\
1,700 \\
\\
12,200 \\
1,750\end{array}$ & $\begin{array}{r}\$ 2.600 \\
500 \\
8,600 \\
\\
26.400 \\
1,720\end{array}$ \\
\hline $\begin{array}{l}\text { Medical, Community Hospital } \\
7 \mathrm{C}\end{array}$ & $\begin{array}{l}\text { Part 170: } \\
\text { Application } \\
\text { Amendment } \\
\text { Inspection } \\
\text { Part 171: } \\
\text { Fee } \\
\text { Surcharge }\end{array}$ & $\begin{array}{r}760 \\
460 \\
1,100 \\
4,600 \\
1.50\end{array}$ & $\begin{array}{r}1,100 \\
500 \\
2,100 \\
\\
5,000 \\
120\end{array}$ \\
\hline $\begin{array}{l}\text { Industrial Radiography } \\
3 \mathrm{O}\end{array}$ & $\begin{array}{l}\text { Part 170: } \\
\text { Application } \\
\text { Amendment } \\
\text { Inspection } \\
\text { Part 171: } \\
\text { Fee } \\
\text { Surcharge }\end{array}$ & $\begin{array}{r}3,200 \\
520 \\
1,300 \\
\\
12,800 \\
150\end{array}$ & $\begin{array}{r}3,800 \\
690 \\
3,500 \\
\\
17,000 \\
120\end{array}$ \\
\hline $\begin{array}{l}\text { Well Logging } \\
5 \mathrm{~A}\end{array}$ & $\begin{array}{l}\text { Part 170: } \\
\text { Application } \\
\text { Amendment } \\
\text { Inspection } \\
\text { Part 171: } \\
\text { Fee } \\
\text { Surcharge }\end{array}$ & $\begin{array}{r}3,600 \\
580 \\
860 \\
\\
10.300 \\
150\end{array}$ & $\begin{array}{r}3,700 \\
650 \\
3,600 \\
\\
11,100 \\
120\end{array}$ \\
\hline $\begin{array}{l}\text { Nuclear Laundry } \\
6 \mathrm{~A}\end{array}$ & $\begin{array}{l}\text { Part 170: } \\
\text { Application } \\
\text { Amendment } \\
\text { Inspection } \\
\text { Part 171: } \\
\text { Fee } \\
\text { Surcharge }\end{array}$ & $\begin{array}{r}1,500 \\
370 \\
1,300 \\
\\
5,100 \\
1,750\end{array}$ & $\begin{array}{r}4,500 \\
700 \\
4,500 \\
\\
13,700 \\
1,720\end{array}$ \\
\hline $\begin{array}{l}\text { Portable Gauge } \\
3 \mathrm{P}\end{array}$ & $\begin{array}{l}\text { Part 170: } \\
\text { Application } \\
\text { Amendment } \\
\text { Inspection } \\
\text { Part 171: } \\
\text { Fee } \\
\text { Surcharge }\end{array}$ & $\begin{array}{r}540 \\
410 \\
1,300 \\
2,100 \\
150\end{array}$ & $\begin{array}{r}570 \\
360 \\
1,500 \\
\\
2,000 \\
120\end{array}$ \\
\hline
\end{tabular}

'For FY92, NRC charged separate fees for routine and nonroutine inspections. Only the fee for the routine inspection is shown. For FY93, the NRC has proposed that the nonroutine inspection fee be dropped. 

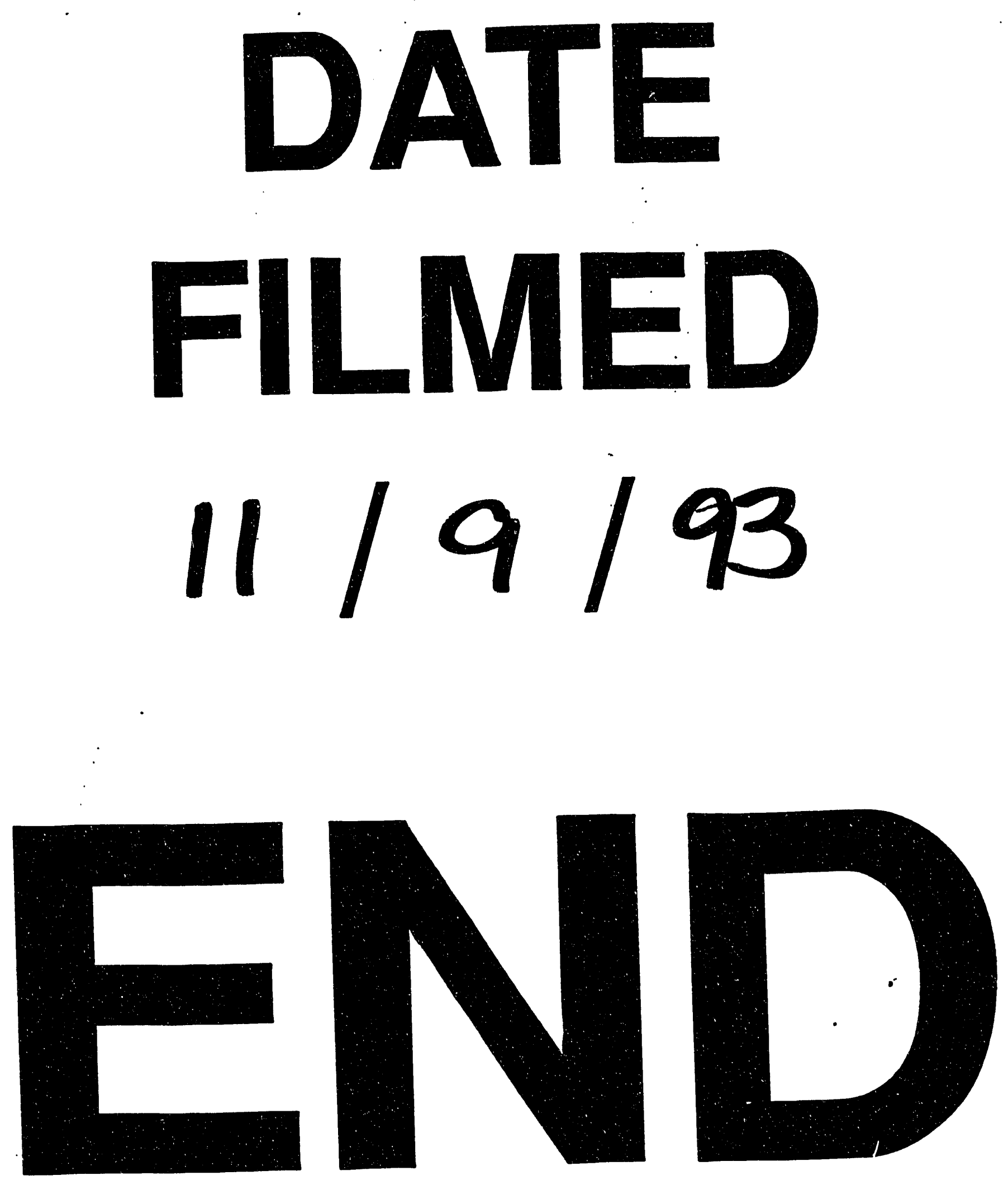
